\title{
THREE CASES OF MALIGNANT HYPERTHERMIA WITH SPECIAL CONSIDERATION OF MANAGEMENT
}

\author{
B. A. BRITT, M.D., DIP.ANAES., F.R.C.P.(c), AND \\ R. A. GoRDON, M.D., F.R.C.P.(C), F.F.A.R.C.S."
}

Malignant Hyperthermia was first described by Guedel in $1952 .{ }^{1}$ A further 80 cases have since been reported, and we are aware of about 40 more unreported cases. ${ }^{2-27}$ The high mortality rate ensuing from this unusual condition has not been reduced over the years. It still remains above 70 per cent. ${ }^{28}$ In this paper we propose first to present three previously unpublished episodes of malignant hyperthermia which have been reported to us in the course of our investigations of this syndrome. One of these patients survived and two died. Secondly we wish to discuss the management of this grave problem.

Malignant hyperthermia is characterized by fever often associated with rigidity following the administration of muscle relaxants and/or potent inhalational anaesthetic agents. Its clinical attributes have been more fully described in previous papers. ${ }^{28,20}$

This syndrome appears to be due to a marked acceleration of muscle and liver metabolism with a consequent marked increase in consumption of oxygen, production of carbon dioxide and non-volatile acids, release of intracellular potassium into the extracellular fluid, and passage of myoglobin into the urine. Blood clotting fails and haemoglobin also appears in the urine in large quantities. The reason for the acceleration of tissue metabolism still remains obscure.

\section{Description of Cases}

Case 1, D.J.

A 38-year-old healthy white male was admitted to hospital for treatment of a traumatic herniated nucleus pulposus at L4-5 by laminectomy and spinal fusion. The patient had two younger sisters who had both expired prematurely. The younger had died the previous year at the age of 24 years from a hyperthermic reaction which developed during a cholecystectomy. The older, a diabetic, had died rather suddenly at the age of 24 years, while apparently convalescing from pleurisy. Death was thought at the time to be due to a cerebrovascular accident. Three children of the patient are all alive and well. One son has had an uneventful inguinal hernia repair under cyclopropane anaesthesia.

The patient himself had undergone three previous uneventful anaesthetics: a tonsillectomy and adenoidetcomy at the age of 8 years; an appendectomy at the age of 25 years employing thiopentone, cyclopropane, and d-tubocurarine chloride; and a right inguinal hemia repair using thiopentone and cyclopropane. The maximum temperature rise recorded during these hospitalizations was $100^{\circ} \mathrm{F}$.

'Departments of Anaesthesia and Pharmacology, University of Toronto. 
Anaesthesia was induced at 0900 hours with thiopentone $375 \mathrm{mg}$ followed by succinylcholine $60 \mathrm{mg}$ intravenously. The patient was ventilated without difficulty with oxygen and intubated with a number 11 Magill orotracheal tube. Following intubation, anaesthesia was maintained with nitrous oxide $4 \mathrm{~L}$, oxygen $2 \mathrm{~L}$, and halothane. After the patient was placed in the prone flexed position, $40 \mathrm{mg}$ of gallamine was given and respiration was assisted manually.

Half an hour after surgery had commenced the blood appeared somewhat dark and the muscles of the arms rather tense. A further $20 \mathrm{mg}$ of gallamine did not reduce the muscle tone and, in fact, muscle tone actually increased considerably over the following thirty minutes, necessitating another $20 \mathrm{mg}$ of gallamine. Marked cyanosis of skin and darkness of blood at the operative site was now evident. The surgeon noticed that blood clotting in the wound was defective. Nasal temperature at 1030 hours was found to be $101^{\circ} \mathrm{F}$. In spite of ice packs and hyperventilation the temperature rose to $104^{\circ} \mathrm{F}$ over the next thirty minutes. At this time the oxygen concentration in the inspired gas was increased to 50 per cent.

On completion of the surgery at 1115 hours the patient was placed on a cooling blanket. Five minutes later the temperature was $107^{\circ} \mathrm{F}$ and the blood pressure was 50/?. At 1230 hours the temperature was $99^{\circ} \mathrm{F}$ and at 1330 hours $92^{\circ} \mathrm{F}$. For the next four hours the temperature remained at $90^{\circ} \mathrm{F}$. Marked acidosis ( $\mathrm{pH}$ 6.6, $\mathrm{Pa}_{\mathrm{CO}_{2}} 150 \mathrm{~mm} \mathrm{Hg}$, and $\mathrm{BE}-30 \mathrm{mEq} / \mathrm{L}$ ) was treated with large doses of sodium bicarbonate. Promethazine was also administered.

The patient remained comatose and exhibited opisthotonus and spasticity. The pupils were dilated and equal and failed to react to light. The aqueous and vitreous were semicrystallized and there appeared to be ischaemia of the left retina. There did not appear to be any neurological or endocrine lesion present which might produce a fever, such as a ruptured cerebral aneurysm, or a pheochromocytoma.

At 1730 hours the patient appeared to be rousing slightly and so ventilatory assistance was discontinued. Over the next twenty hours he sustained several episodes of profound shock which were treated with Rheomacrodex, steroids, and sodium bicarbonate. Total urinary output was about $100 \mathrm{cc}$ of red urine which was positive for haemoglobin. Direct and indirect Coombs tests were negative and rematching of transfused blood showed no incompatibility.

The patient expired 28 hours after induction of the anaesthetic. Autopsy revealed only oedema of the brain, lungs, and kidneys.

\section{Case 2, M.S.}

A five-year-old Jewish male patient in good physical condition was admitted to hospital for repair of a left lateral strabismus. Ptosis of the left eye was also present. An older brother had previously had two non-fatal hyperthermic episodes in another city. This brother and four other male members of the family all suffered from ptosis and left lateral strabismus. Two had had previous anaesthetics without ill effect.

The patient was premedicated with pethidine $75 \mathrm{mg}$ and atropine $0.3 \mathrm{mg}$. The preoperative temperature was normal. Anaesthesia was induced at 1.140 hours with halothane 1.5-2.0 per cent and nitrous oxide $4 \mathrm{~L}$ and oxygen $2 \mathrm{~L}$ in a 
Digby-Leigh circuit. A number 24 Collins tube was inserted without difficulty. The anaesthetic was maintained with the same agents.

During the operation the respiratory rate rose to 36 per minute and the heart rate to 130 per minute. Otherwise the procedure appeared to be uneventful.

On arrival in the recovery room at 1250 hours the patient was unreactive, the heart rate was 160 per minute, the skin was cyanosed and sweating, and the temperature was $107^{\circ} \mathrm{F}$. Twitching of the left side of the face rapidly progressed to a grand mal convulsion. The child was ventilated with 100 per cent oxygen, cooled with a hypothermia blanket and ice packs and buffered with $50 \mathrm{cc}$ of $7 \frac{1}{2}$ per cent sodium bicarbonate. In spite of these measures the temperature continued to rise to $108^{\circ} \mathrm{F}$. The electrocardiogram showed diffuse myocardial damage which shortly progressed to ventricular fibrillation and then asystole. Cardiac massage and intracardiac epinephrine were without avail and the patient was declared dead at 1617 hours.

Case 3, M.A.

A four-year-old healthy white female was admitted to hospital for an elective tonsillectomy and adenoidectomy. The child had not previously been anaesthetized. Two younger siblings had both expired in infancy - a sister of pneumonia and a brother in his crib of unknown causes.

Premedication consisted of pentobarbital supp. $30 \mathrm{mg}$, pethidine $25 \mathrm{mg}$, and atropine $0.3 \mathrm{mg}$. Preoperative temperature was normal.

Anaesthesia was induced at 0910 hours with cyclopropane and oxygen through an open-ended tube until crying had ceased and then $100 \mathrm{mg}$ of thiopentone was given followed by $25 \mathrm{mg}$ of succinylcholine intravenously. After the administration of the succinylcholine the jaws clamped firmly shut. Intubation with a number 5 red rubber endotracheal tube was accomplished with some difficulty and insertion of the mouth gag also proved troublesome. The chest on the other hand was easily inflated.

Anaesthesia was maintained with nitrous oxide $3 \mathrm{~L}$ and oxygen $3 \mathrm{~L}$ and halothane 1.5 per cent, using an MIE infant set. Because of continued failure of relaxation, methoxyflurane was introduced at 0918 hours and halothane was discontinued at 0923 hours.

During the procedure the heart rate rose to 165 per minute and the respirations to 40 per minute. The blood remained dark throughout the surgery in spite of vigorous hyperventilation with oxygen flushing.

The patient was admitted to the recovery room at 0950 where the rectal temperature was found to be $104^{\circ} \mathrm{F}$ and the skin cyanosed. Respirations were 50 to 60 per minute. Cold sponges were applied and pethidine $20 \mathrm{mg}$ and phenobarbital $30 \mathrm{mg}$ given. At 1345 hours the rectal temperature was $106^{\circ} \mathrm{F}$. The child was reintubated, hyperventilated with 100 per cent oxygen, and infused with two-thirds 5 per cent glucose in water and one-third normal saline and cooled in ice packs.

A sinus tachycardia was present on the electrocardiogram. The $\mathrm{pH}$ was 7.26 , the $\mathrm{Pa}_{\mathrm{CO}_{2}} 36 \mathrm{~mm} \mathrm{Hg}$, the $\mathrm{CO}_{2}$ content $16 \mathrm{mEq} / \mathrm{L}$, serum potassium $5.2 \mathrm{mEq} / \mathrm{L}$, and the prothrombin time was 30 seconds.

At 1530 hours the temperature had fallen to $100^{\circ} \mathrm{F}$. Fifty cc of 5 per cent 
sodium bicarbonate was infused. That evening the child voided $160 \mathrm{cc}$ of dark burgundy urine which was $4^{+}$for blood and $2+$ for protein. The $\mathrm{pH}$ was 7.31 , $\mathrm{Pa}_{\mathrm{CO}_{2}}$ was $29 \mathrm{~mm} \mathrm{Hg}$, and the $\mathrm{CO}_{2}$ content was $14.7 \mathrm{mEq} / \mathrm{L}$. The temperature at this time was normal.

For four days the child remained drowsy and irritable. On the fourth postoperative day clinical jaundice was evident and the liver was palpable two finger breadths below the costal margin. The van den Bergh was $4.9 \mathrm{mg}$ per cent direct and $1.8 \mathrm{mg}$ per cent indirect. The blood urea nitrogen was $61 \mathrm{mg}$ per cent. Coarse granular casts were seen in the urine and the urine was $1+$ for bilirubin and $2+$ for urobilin.

On the fifth postoperative day clinical and laboratory improvement was noticeable. By the eighth postoperative day the child was alert, co-operative, and having a vigorous diuresis. At that time the blood urea nitrogen was $22 \mathrm{mg}$ per cent, the direct bilirubin was $1.7 \mathrm{mg}$ per cent, and the indirect bilirubin was $0.8 \mathrm{mg}$ per cent. She was discharged from hospital on the ninth day following surgery and has since remained well and progressed satisfactorily at school.

Several months after the anaesthetic described, a maternal uncle suffered an episode of prolonged muscle stiffness during a tonsillectomy.

\section{Discussion}

\section{Prevention}

The abnormality which leads to the development of malignant hyperthermia appears to be an autosomal dominant trait. ${ }^{329}$ Therefore, in affected sibships one can expect that fifty per cent of the offspring will be afflicted. Thus when a patient is known to have relatives who manifest the trait it is wise to avoid the use of muscle relaxants or potent inhalational agents, as all have been incriminated in the production of this lethal syndrome. . $^{1-27}$

A number of affected patients have been managed safely with some form of local, regional, or conduction anaesthesia. ${ }^{2,3,24,27}$ Where this proves impractical a combination of nitrous oxide, oxygen, and a narcotic mixture has been used successfully in at least one affected patient. ${ }^{16,22}$

A history of previous normal anaesthetics does not rule out the possibility of the occurrence of malignant hyperthermia, ${ }^{9,11,27}$ especially if the anaesthetic was of short duration or was administered to a child under the age of three years, as this syndrome has never been observed prior to this age.

\section{Early recognition}

The importance of early recognition of malignant hyperthermia cannot be overemphasized. One of the most consistent initial signs is inadequate relaxation or frank rigidity following the administration of succinylcholine or other muscle relaxant or inhalational agent. A thermistor or thermocouple type of temperature probe inserted into a body orifice will detect early temperature rises. Other early clinical signs include dark blood, cyanosis of the skin, tachycardia and other arrhythmias, rapid shallow respirations, and excessive heat of the soda lime canister and anaesthetic reservoir bag. 
In the more terminal stages there is marked rigidity of all muscles, extreme hyperthermia, hypotension, a weak thready pulse, failure of blood clotting, and oliguria. Laboratory findings include extreme respiratory and metabolic acidosis, hyperkalaemia, and the presence of haemoglobin and myoglobin in the urine.

\section{Therapeutic management}

a. Metabolic acidosis. Control of the formidable acidosis is of the first importance. Massive doses of buffers are necessary to correct the enormous base deficits which have been recorded, as for example the base deficit of $-30 \mathrm{mEq} / \mathrm{L}$ in case 1. Since malignant hyperthermia appears to be of intracellular origin, with the metabolic acidosis being due to accelerated production of hydrogen ions within the cell, on a theoretical basis THAM would appear to be the buffer of choice, rather than sodium bicarbonate. ${ }^{31}$ However, many patients have been successfully treated with sodium bicarbonate alone, and the factor of major importance is that the treatment should be prompt and adequate.

Because of the alteration of the buffering capacity of the blood as the body temperature rises, ${ }^{32}$ and because in most laboratories $\mathrm{pH}$ is generally measured at $38^{\circ} \mathrm{C}$, the $\mathrm{pH}$ values must be corrected for actual body temperature. This can readily be done by using a transposition of Rosenthal's anaerobic equation ${ }^{33}$ as follows:

$$
\mathrm{pH}_{t}=\mathrm{pH}_{38}+0.0147(38-t)
$$

where $t=$ actual body temperature in ${ }^{\circ} \mathrm{C}$.

b. Respiratory acidosis. The marked acceleration of carbon dioxide production in the peripheral tissues necessitates artificial hyperventilation at least in the order of two or three times the minute volume suggested by the Radford nomogram. Because of rigidity of the muscles of the chest wall rather higher than normal inspiratory pressures may be required.

Arterial $\mathrm{PCO}_{2}$ values should be corrected for actual body temperature according to the equation of Siggaard-Andersen: ${ }^{34}$

$$
\mathrm{PCO}_{2_{\mathrm{t}}}=\operatorname{antilog}\left(\log \mathrm{PCO}_{2_{38}}-0.21(38-t)\right) \text {. }
$$

c. Anoxaemia. Ventilation with 100 per cent oxygen is necessary to maintain arterial oxygen tension within the normal range, even though pulmonary function is entirely normal. In spite of this measure a large A-a oxygen difference can be expected due to the massive acceleration of oxygen consumption by the tissues.

d. Fever. Vigorous cooling is necessary to lower the patient's temperature to the normal range. The use of alcohol sponges, ice packs, or a hypothermia blanket may not be adequate. ${ }^{12,14,30}$ Gastric and rectal cooling and perhaps even perfusion cooling may be required.

e. Hyperkalaemia. Adequate control of the acidosis may serve to lower the 
serum potassium values to acceptable levels. The administration of glucose and insulin by the intravenous infusion of 5 per cent dextrose solution containing 50 units of regular Toronto insulin in $1000 \mathrm{ml}$ is a useful adjunct, but in view of the large volumes of buffering solutions which are required in this situation serious attention must be directed to the possibility of circulatory overload in the presence of depressed myocardial function. If these measures are ineffective it may be necessary to resort to peritoneal or haemodialysis.

f. Rebound phenomena. While it is essential to lower body temperature and serum potassium to normal levels, excessively low levels must be avoided, as these may be just as lethal as the previous high levels. To prevent such rebound phenomena, continuous temperature monitoring and frequent serial measurements of serum potassium are indicated.

\section{SUMMARY}

Three cases of malignant hyperthermia during anaesthesia have been presented, which illustrate some of the problems commonly encountered in the management of this syndrome.

Prevention, early recognition, and therapeutic management of malignant hyperthermia have been discussed. The importance of detection of afflicted relatives is stressed. Early diagnosis and treatment are essential to prevent death. The mainstays of treatment are cooling, buffers, hyperventilation with oxygen, and frequent monitoring of temperature, serum electrolytes, blood gases, and urine output.

\section{RÉSUMÉ}

On rapporte trois cas d'hyperthermie maligne durant l'anesthésie; ces cas illustrent quelques uns des problèmes que l'on rencontre généralement dans le traitement de ce syndrome.

On a discuté de la prévention, du diagnostic précoce et de la conduite du traitement de l'hyperthermie maligne. On insiste sur l'importance de découvrir ce trouble parmi les parents de ceux qui sont afligés de ce syndrome. Le diagnostic et le traitement précoces sont essentiels pour prévenir la mort. Les points principaux du traitement sont le refroidissement, les tampons, l'hyperventilation à l'oxygène et un compte rendu fréquent de la température, des électrolytes du sérum, des gaz sanguins et du débit urinaire.

\section{ACKNOWLEDGMENTS}

The authors wish to thank Dr. Norman Foster, Calgary, Alberta, Dr. R. Kilborn, Kitchener, Ontario, and Dr. G. Sanderson, Buffalo, New York, for permission to publish the case reports included in this presentation.

\section{REFERENCES}

1. Gueder, A. E. Inhalation Anaesthesia. 2nd ed., New York: Macmillan (1952).

2. Denborough, M. A. \& LovelL, R. R. H. Anaesthetic Deaths in a Family. Lancet. 2: 45 (1960). 
3. Denborouch, M. A.; Forster, J. F. A.; Lovell, R. R. H.; Maplestone, P. A.; \& Villiers, J. D. Anaesthetic Deaths in a Family. Brit. J. Anaesth. 34: 395 (1962).

4. Ruttle, L. D. Case Report 247: Death Occurred in the Operating Room Following Extreme Hyperthermia during an Elective Cholecystectomy. American Society of Anesthesiologists' Newsletter (July 1962), p. 21.

5. W. A. C. (Calif.) Comment on Case Report No. 247. American Society of Anesthesiologists' Newsletter (August 1962), p. 30.

6. P.S.M. (Mass.) Comment on Case Report No. 247. American Society of Anesthesiologists' Newsletter (November 1962), p. 10.

7. Samman, L. J.; Havard, E. S.; \& Eger, E. I. Hyperthermia during anesthesia. J.A.M.A. 190: 1029 (1964).

8. Carpenter, G. G.; Auerbach, V. H.; Digeorge, A. M.; Mayer, B. W; \& Schutta, H. S. Rhabdomyolysis after Routine Administration of Succinylcholine in Children. Soc. Paediat. Res. April 29-30, p. 175 (1966).

9. Relton, J. E. S.; Creighton, R. E.; Johnston, A. E.; Pelton, D. A.; \& Conn, A. W. Hyperpyrexia in Association with General Anaesthesia in Children. Canad. Anaesth. Soc. J. 13: 419 (1966).

10. Thut, W. H. \& Davenport, H. T. Hyperpyrexia Associated with Succinylcholine-induced Muscle Rigidity; A Case Report. Canad. Anaesth. Soc. J. 13: 419 (1966).

11. Hogg, S. \& Renwick, W. Hyperthermia during Anaesthesia. Canad. Anaesth. Soc. J. 13: 429 (1966).

12. Cullen, W. G. Malignant Hyperpyrexia during General Anaesthesia: A Report of Two Cases. Canad. Anaesth. Soc. J. 13: 437 (1966).

13. Lavoie, G. Hyperpyrexia during General Anaesthesia: A Case Report. Canad. Anaesth. Soc. J. 13: 444 (1966).

14. Davies, L. E. \& Graves, H. B. Hyperpyrexia and Death Associated with General Anaesthesia. Canad. Anaesth. Soc. J. 13:447 (1966).

15. Gondon, R. A. Malignant Hyperpyrexia during General Anaesthesia. Canad. Anaesth. Soc. J. 13: 415 (1966).

16. Relton, J. E. S.; Creighton, R. E.; Conn, A. W.; \& Nabeta, S. Generalized Muscular Hypertonicity Associated with General Anaesthesia: A Suggested Anaesthetic Management. Canad. Anaesth. Soc. J. 14: 22 (1967).

17. Purkis, I. E.; Horrelt, O.; DeYounc, G.; Fleming, R. A. P.; \& Lancley, G. R. Hyperpyrexia Following Anaesthesia in a Second Member of a Family, with Associated Coagulation Defect. Canad. Anaesth. Soc. J. 14: 183 (1967).

18. Stepiren, C. R. Fulminant Hyperthermia during Anesthesia and Surgery. J.A.M.A. 202: 178 (1967).

19. Wrlson, R. D.; Dent, T. E.; Traber, D. L.; McCoy, N. R.; \& Allen, C. R. Malignant Hyperpyrexia with Anesthesia. J.A.M.A. 202: 183 (1967).

20. Churchull-Davidson, H. C. Malignant Hyperpyrexia. Brit. Med. J. 5610: 69 (1968).

21. CoDy, J. R. Muscle Rigidity Following Administration of Succinylcholine. Anesthesiology 29: 159 (1968).

22. Relton, J. E.; Creighton, R. E.; \& Conn, A. W. Fulmịnant Hyperpyrexia Associated with Anaesthesia. Anaesthesia 23: 253 (1968).

23. McKeE, R. S. Personal communication (1968).

24. Kruse, J. C. Personal communication (1968).

25. Papper, E. M. Personal communication (1968).

26. Gygi, A. Personal communication (1968).

27. Locher, W. G. Personal communication (1968).

28. Britt, B. A. \& Kalow, W. Hyperrigidity and Hyperthermia Associated with Anesthesia. Ann. N.Y. Acad. Sc. 151: 947 (1968).

29. Britt, B. A.; Locher, W. G.; \& Kalow, W. Hereditary Aspects of Malignant Hyperthermia. Canad. Anaesth. Soc. J. 16: 89 (1969).

30. Stephen, C. R. Personal communication (1967).

31. Monrıs, L. Personal communication (1967).

32. Fell, R. H. \& Dendy, P. R. Severe Hypothermia and Respiratory Arrest in Diazepam and Glutethimide Intoxication. Anaesthesia. 23: 636 (1968).

33. Rosentrial, T. B. The Effect of Temperature on the $\mathrm{pH}$ of Blood and Plasma in Vitro. J. Biol. Chem. 173: 25 (1948).

34. Siggaard-Andersen, $O$. The XYZ of Blood Acid-Base Chemistry. Proc. Assoc. Clin. Biochem. 2: 137 (1963). 